(19)

\title{
肩関節外転運動における菱形筋を中心とした 肩甲骨周囲筋群の筋活動特性
}

\author{
橘内基純 ${ }^{1 \dagger}$ ，金子文成 ${ }^{2,3}$, 青山敏之 ${ }^{4}$, 戸田創 ${ }^{4}$, 福林徹 ${ }^{5}$ \\ ${ }^{1}$ 早稲田大学大学院スポーツ科学研究科, ${ }^{2}$ 札幌医科大学保健医療学部理学療法学科, \\ 3独立行政法人産業総合技術研究所人間福祉医工学研究部門, \\ ${ }^{4}$ 札幌医科大学大学院保健医療学研究科, ${ }^{5}$ 早稲田大学入ポーツ科学学術院

\begin{abstract}
要旨 本研究では, 菱形筋を中心とした肩関節外転運動における肩甲骨周囲筋群の筋活動量の変 化を検討することを目的とした，対象は肩関節に既往のない健常男子大学生 6 名とし，肩関節外 転運動時の大 ・ 小菱形筋の筋活動をワイヤ電極により, 前鋸筋, 僧帽筋中部線維の筋活動を表面 電極により計測した。この結果，小菱形筋と大菱形筋間において筋活動量に差異が認められると ともに, 小菱形筋と前鋸筋の 2 筋は負荷の増加に伴って筋活動量が増加する傾向が見られた。 って, 小菱形筋と前鋸筋は負荷依存的に活動することが考えられ, 肩関節外転運動に伴う肩甲胸 郭関節の運動は肩甲骨周囲筋群の協調運動により遂行されている可能性が示唆された。
\end{abstract} \\ キーワード : 菱形筋, 僧帽筋, 肩甲胸郭関節, ワイヤ筋電図, オーバーヘッドスポーツ
}

\section{1.はじめに}

肩甲胸郭関節は機能的関節といわれ，骨構造のよ うな構造的関節とは異なり, その運動における安定 性は構築学的ではなく, 周囲筋の協調による力学的 作用によりもたらされる，例えば，肩関節外転運動 では肩甲骨の上方回旋，外転，及び後傾が付随する が，これらのような複合運動を円滑に遂行するため には，僧帽筋や前鋸筋，大・小菱形筋，肩甲挙筋な どの肩甲骨周囲筋の協調した活動によって発生する Force Couple（偶力）が重要な働きをしているとさ れる.

野球やテニスといったオーバーヘッドスポーツに おいて, 肩関節及び肩甲骨運動はパフォーマン
$ス^{1 \sim 3)}$ や障害予防 ${ }^{4,5)}$ といった観点からも重要な役割 を担う身体機能である，特に，野球の投手やテニス のサービス動作では，肩甲上腕関節と肩甲胸郭関節 により大きな可動域での高速度運動が可能となり， 関節部に损ける回旋速度や力を生み出すと言われて いる ${ }^{2)}$.しかし, 肩関節障害の発生により, 肩甲骨 運動は異常をきたすことが報告されている6). この ときの筋活動を見てみると, 肩甲骨運動のための偶 力を生成する僧帽筋と前鋸筋間との筋活動の量的バ ランスが正常な場合と異なることが Ludewig et $\mathrm{al}^{7)}$ や Kibler et $\mathrm{al}^{8)}$ により述べられている. 従っ て, オーバーヘッド動作による肩関節機能障害を予 防抢よび治療するためには, 肩甲骨運動の詳細なメ カニズムをより深く理解し, その知見からエクササ イズ方法などを構築することが必要であると考え 
る。

これまでの研究においては, 僧帽筋と前鋸筋にお ける肩甲骨運動の偶力の説明がなされてきてはいる ものの，菱形筋を含めた肩甲骨周囲筋群の筋間の協 調に関する研究は検索した限りではない. 菱形筋 は，肩甲骨を内転位に保持する働きがあると考えら れている。 また肩甲骨内側縁で前鋸筋と付着部が近 接していることなどから, 他の周囲筋とともに肩甲 骨の協調運動に影響を与えているものと考える。過 去には, Inman $ら^{9)}$ が菱形筋の筋活動について報告 しているものの，周囲筋との関連性や詳細な機能に ついて言及しているものはない。

そこで本研究に抢いては, 肩関節外転運動におけ る菱形筋を中心とした肩甲骨周囲筋群の筋活動量の 変化を検討することを目的とした。

\section{2. 方法}

\section{1 対象}

肩関節に既往のない健常な男子大学生 6 名（24.3 $\pm 0.5[\mathrm{yrs}], \quad 175.6 \pm 5.3[\mathrm{~cm}], \quad 71.3 \pm 5.9[\mathrm{~kg}]$ : mean $\pm \mathrm{SD} ）$ の右肩を対象とした。被検者はすべて 右利きであった，被験者には，事前に早稲田大学入 ポーツ科学学術院倫理委員会並びに独立行政法人産 業総合技術研究所人間工学実験倫理委員会により承 認された説明書により文書及び口頭にて実験に関す る十分な説明を行い, 同意後署名を得た.

\section{2 運動課題}

被験者は立位姿勢にて, 肩関節外転運動を行っ た。肩関節外転運動における負荷量は $0,1 ， 2[\mathrm{~kg}]$ の 3 種類とし, 負荷の方法としてダンベルを用い た１回の試技における時間は3[秒]とし，60[拍／ 分〕に設定した電子メトロノーム $(\mathrm{ME}-50$,

YAMAHA，Japan）を使用することにより，一定 速度で試技を行った。 なお，動作課題に慣れるた め，試技開始前に十分に練習を行った。また，一つ の負荷量に対し試技を2[回]ずつ行った.

また測定時家庭用ビデオカメラ 2 台 $(30[\mathrm{~Hz}]$,

Panasonic and Sony）を用いて前額面・矢状面から
撮影を行い, 二次元 - 三次元動作解析ソフト Flame Dias-II（DKH，Japan）を用いて肩関節外 転角度を算出した。算出はパンニング DLT 法を用 い二次元平面上より行った。身体計測点は, 局峰, 肩甲棘遠位端, 上腕骨外側上顆, 橈骨茎状突起, 第 7 頸椎, 第 5 胸椎とし, 春柱に対する肩峰一上腕骨 外側上顆点間の移動を肩関節移動角度とした。個人 間の肩関節可動域（ROM：Range of Motion）によ る影響を除外するために, 測定の対象とする可動域 を肩関節外転 $0\left[^{\circ}\right] \sim 135\left[^{\circ}\right]$ とした。 また, 運動速 度について，電子メトロノームにより規定したもの と実際の運動速度との間でずれる可能性があったた め, 画像上にて正確性を確認した。検討した結果, 運動時間が $3.0 \pm 0.1$ 秒の範囲内に当てはまらない ものは解析対象から除外した。

動作は疲労の影響を除去するため, 試技毎に十分 な休息時間を設けた。また，筋電図と動画を同期さ せるために，光抢よび電気信号発生装置を用いた． この装置は，検者がスイッチを押すと LED が点灯 し，その光信号と同期して $5[\mathrm{~V}]$ 振幅の矩形波を発 生させるものであった，光信号は，ビデオカメラ 2 台の画角に収まるように設置し, 矩形波の電気信号 は, 筋電図と共に Analogue to Digital 変換ボード (NI SCXI 1000, National Instruments, Japan) を 経由してパーソナルコンピュータ（VAIO, Windows XP, Sony, Japan) に取り込んだ。この 同期の方法では, 動画撮影の周波数から $30[\mathrm{msec}]$ 未満のずれが, ビデオカメラ 2 台㧍よび筋電図信号 の 3 者間で生じる可能性があった。しかし, 今回の 課題とした動作は 3 秒間と, 予測されるずれ時間か らは十分に長い動作時間と判断し，あらかじめその ずれは容認した。

\section{3 筋電図計測及び処理}

まずワイヤ電極刺入に際しては, オートクレーブ により滅菌処理されたカテラン針を用いた。刺入の 前には, アルコールによる消毒を行った，刺入に使 用した $23 \mathrm{G}$ のカテラン針内にあるワイヤ電極は, 複合的な動きを呈す肩甲骨周囲筋群の筋活動に対応 するために, 直径 $50[\mu \mathrm{m}]$ のウレタンコーティン 


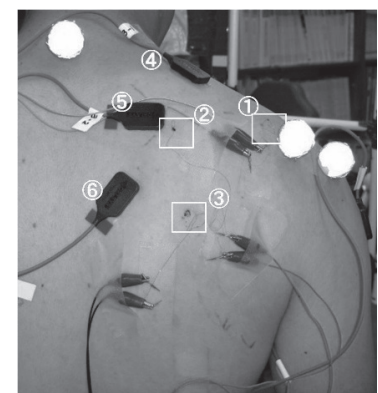

図 1 ワイヤ電極及び表面電極貼付位置 ; (1)棘上筋, (2)小菱 形筋, (3)大菱形筋, (4)僧帽筋上部線維, (5)僧帽筋中部 線維, (6)僧帽筋下部線維（出典：執筆者)

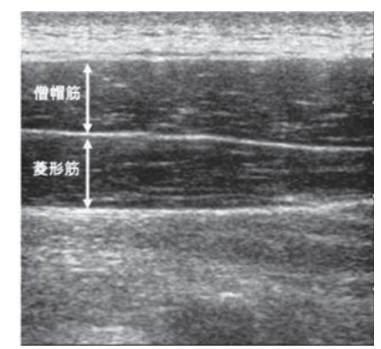

図 2 超音波画像による僧帽筋及び菱形筋断層像（出典：執 筆者)

グされたファインワイヤ電極（双極貼合ワイヤー電 極 TN208-018, Unique Medical, Japan）を用いた.

ワイヤ電極の刺入は, 小菱形筋, 大菱形筋の 2 筋 に対し行い，双極誘導によりそれぞれの筋活動を導 出した（図 1). そして, ワイヤ電極の刺入の後に 超音波エコー像（Volson I, G.E., Japan）により刺 入の位置と刺入された針先の位置を確認した。さら に電気刺激装置 (EMG Electronic Stimulator SEM-42D1，日本光電，Japan）を使用して, 電極 に電気刺激を加えることにより大・小菱形筋それぞ れが単独で収縮することを確認した。これによりワ イヤ電極の刺入位置が適切であるかどうかを判断し た（困 2).

次に表面電極貼付時にはアルコールによる除菌, 皮膚研磨材 skin pure を用いた皮膚抵抗の除去を行 った。 そして, 能動型表面電極（D.E-2.1, Delsys, USA）を用い, 僧帽筋中部線維, 前鋸筋より双極 誘導にて筋活動を導出した。

電極の装着後, 徒手筋力検査法 (MMT : Manual Muscle Test）を行い, 各筋から適切な筋活動が記
録されるかどうかを確認した，本研究における菱形 筋の MMT は, 肩関節内旋 · 肘関節 $90\left[^{\circ}\right]$ 屈曲位で 前腕が肩甲骨後面に位置する肢位にて，肩甲骨内転 運動を行う方法により計測した.

筋電図記録・処理に関しては, 金子ら ${ }^{10,11)}$ の方法 に基づいて行った。サンプリング周波数は 2000 $[\mathrm{Hz}]$ とし, フィルタ処理及び整流平滑化（ARV： Average Rectified Value) はオフラインで行った (Lab View ver6.0, National Instruments Corp, USA)。フィルタは低域通過フィルタを使用し, 低 域遮断周波数を $5[\mathrm{~Hz}]$, 次数を 4 とした. フィル夕 処理後, $5[\mathrm{~Hz}]$ の低域通過フィルタ（2次の低域通 過フィルタ）により平滑化し ARVを算出した. 結 果はそれぞれの筋において，5秒間の最大随意収縮 (MVC : Maximum Voluntary Contraction) 時に記 録した筋電図について，中間の 1 秒間の ARVを 100[\%]とし, 正規化した。

各試技で得られた $\mathrm{EMG}$ デー夕及び角度データ は，個人間における比較及び同期を行うために，角 度データにより正規化した。それらのデータは MATLAB ver. 7.3 (The MathWorks Inc., USA) により $50[\mathrm{~Hz}]$ ヘダウンサンプリングの後, spline 関数を用いてキュービックスプライン補間を行っ た。補間により EMG データ及び角度データは, 0.2 秒間隔のデータに変換され, トリガーによる同 期を実行することで, 角度基準のデータへ変換し た。

角度変化により規格化された $\mathrm{EMG}$ データ（n ARV : Normalized ARV) を個人内で試技毎に平均 し, 計測值とした。

\section{4 統計学的手法}

n ARV の記載は, すべて平均士標準誤差（mean \pm SE : Standard Error) とした.

また本実験によって得られたnARVに関し，各 筋における角度変化, 筋の種類を要因とした, 二元 配置分散分析を行い, 多重比較検定として Bonferroni 法を行った。また, 有意水準は 5[\%]未 満とした。 

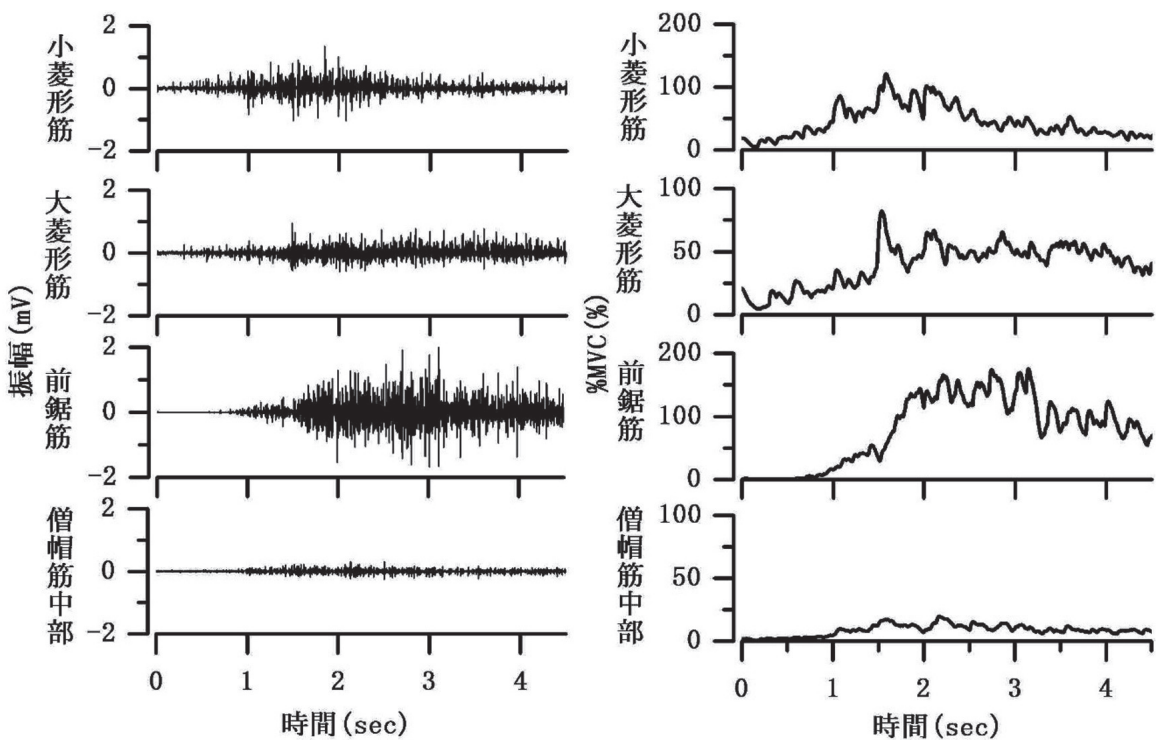

図 3 肩関節外転運動（2[kg]）時の代表的な EMG 生波形と ARV 波形（出典：執筆者）

\section{5 倫理委員会}

本研究は, 早稲田大学スポーツ科学学術院倫理委 員会並びに独立行政法人産業総合技術研究所人間工 学実験倫理委員会の承認を受け，医師立ち会いの下 安全管理体制に十分な注意を払い行われた。

\section{3. 結果}

ある肩関節外転運動（負荷 $2[\mathrm{~kg}] ）$ に伴う代表的 な $\mathrm{EMG}$ 生波形と ARV 波形を図 3 に示す。目視観 察ではモーションアーチファクトの影響は見られな かった。

また，肩関節外転運動を行ったときの各筋におけ る筋活動量の変化について, 図 4, 5, 6 に示す. 図 4 では, 肩関節外転 $0\left[^{\circ}\right]$ から $135\left[^{\circ}\right]$ まで $15\left[^{\circ}\right]$ 毎 の各筋筋活動量の推移について, 負荷毎にその変化 を図示した。さらに，運動中の特定角度における筋 間の差異について，45，90，135[ㅇ] 時の差を図 5 に示した。 その中から, 特に大・小菱形筋間の活動 量の差を図 6 に示した。

小菱形筋は, 大菱形筋に対して安静立位姿勢であ る $0\left[^{\circ}\right]$ の時点で筋活動量が高い傾向にあり, 肩関 節外転角度 $15\left[^{\circ}\right]-45\left[^{\circ}\right]$ では負荷上昇に伴い有意に
筋活動量が増加した $(\mathrm{P}<0.05)$.また, 小菱形筋は 僧帽筋中部線維に対して，0[kg]の負荷においてす べての角度で有意に高值であるのに対して（P< 0.05), 大菱形筋は僧帽筋中部線維とほぼ同程度の 筋活動量の推移を示していた。

前鋸筋では，いずれの負荷に対しても外転 45 $\left[^{\circ}\right]$ 以降急激に筋活動量が高くなる傾向にあり，外 転 75[] ではいずれの負荷においても 4 筋中最も高 い筋活動量を示した。また，外転 $60\left[^{\circ}\right], 90\left[^{\circ}\right]$, $135\left[^{\circ}\right]$ においては大菱形筋, 僧帽筋中部線維に対 して有意に高い筋活動量を示していた $(\mathrm{P}<0.05)$.

これら肩甲骨周囲筋 4 筋の中でも小菱形筋と前鋸 筋は，無負荷である $0[\mathrm{~kg}]$ での筋活動量の角度変 化及び筋間での筋活動差異は小さいものの, 1[kg], 2[kg] と負荷が上昇するにつれて筋活動量が増加す る傾向が見られた。

\section{4. 考察}

本研究では, 肩関節運動における肩甲骨周囲筋, 特に菱形筋に着目し, 小菱形筋, 大菱形筋, 前鋸 筋，僧帽筋中部線維それぞれの筋活動量の関係につ いて検討した。

これまで肩甲胸郭関節の運動 ${ }^{12 \sim 14)}$ や肩甲骨周囲 
（19）肩関節外転運動における菱形筋を中心とした肩甲骨周囲筋群の筋活動特性 221
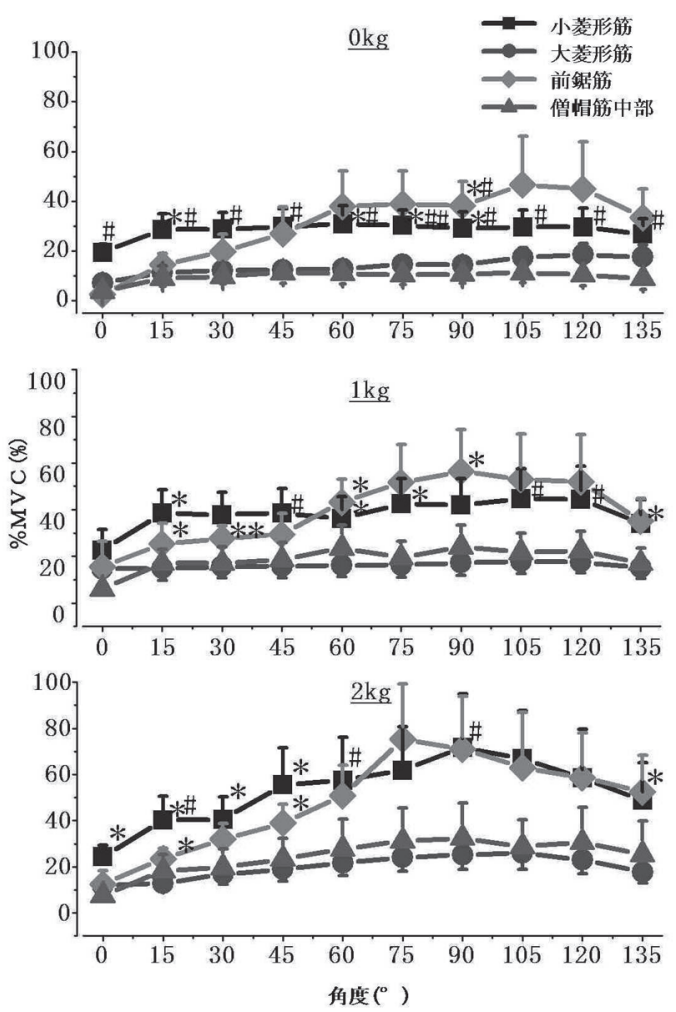

* : 大萲形筋との比較

\# : 僧帽笳中部線維との比較

いずれも $<0.05$, ave $\pm S E$

図 4 肩関節外転運動時の肩甲骨周囲筋群 4 筋の筋活動変化 (出典：執筆者)

筋の偶力や協調性など3.7.15 17) については研究がな されてきたが，その多くが僧帽筋や前鋸筋を対象と しており，菱形筋もしくは菱形筋と他の肩甲骨周囲 筋との筋活動の関連について述べているものは少な い. その理由として，菱形筋は深層筋であるが故に 体表から筋活動を計測することが難しいということ が挙げられる，本研究ではワイヤ電極を用いること により，菱形筋の筋活動を選択的に捉えることを試 みた。この方法として，まず菱形筋から筋電図を記 録できていることを確認するために，超音波エコー 像によるモニタリングと電気刺激を同時に実施し た。これにより, 確実にワイヤ電極が菱形筋に留置 されたことを確認した。また電気刺激では，3〜 5 $[V]$ の低刺激で菱形筋がその線維方向に対して移動 することをモニター上で確認可能であり，僧帽筋中 部線維との筋腹の移動が異なることも確認された.
本研究ではこのような厳密な手順を踏むことで菱形 筋の筋活動を記録するための方法的限界を克服し， 新規的かつ妥当性の高いデー夕を収集することに成 功した.

本研究では, $1[\mathrm{~kg}], 2[\mathrm{~kg}]$ と段階的な負荷の増 加に伴い，小菱形筋及び前鋸筋の筋活動量が僧帽筋 中部線維及び大菱形筋に対して増加する傾向にあっ た. Inman ら ${ }^{9)}$ は肩甲上腕関節における $60\left[^{\circ}\right]$ の外 転運動に対して, 肩甲胸郭関節が $30\left[^{\circ}\right]$ 上方回旋す るという肩甲上腕リズムを提唱している。肩甲上腕 リズムについては，これまで多くの研究が行われて おり，X 線や動作解析 ${ }^{18,19)}$ を用いたものや，近年 では Open MRI ${ }^{20)}$ や fluoroscopy ${ }^{21)}$ などの画像分析 を用いて，両者の関係性について詳細な検討が行わ

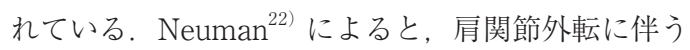
肩甲骨上方回旋は，胸鎖関節と肩鎖関節における運 動の組み合わせにより生じるとしている。また， McQuade et $\mathrm{al}^{23)}$ は, 肩甲骨周囲筋群の疲労が肩甲 骨の不安定性の増大と肩甲上腕リズムの変化を引き 起こすと述べており，これらの報告からもわかるよ うに肩甲上腕関節の運動に対する肩甲胸郭関節の関 与が大きいことが考えられる。

本研究で筋電図を記録した 4 筋は, これまで前鋸 筋と僧帽筋中部線維が肩甲骨上方回旋に，大・小菱 形筋は肩甲骨下方回旋や挙上に作用するとされ，肩 甲骨回旋運動と高い関与があると考えられてきた 22). しかし, 外転 $0 \sim 45\left[^{\circ}\right]$ に扔いて, 大菱形筋は 20[\%]以下と低值であり，高值を示した小菱形筋 に対して有意に低かった。今回統計学的に違いが明 らかになった筋間における筋活動量の差異は, 絶対 值ではなく，あくまでも筋固有の MVC 時の筋活動 量を基準とした相対的なものである。したがって, 本研究で示された, 肩関節外転運動における小菱形 筋と大菱形筋の筋活動量が異なっていたことは，そ の差を生じた関節可動域において, 筋固有の最大随 意収縮で発揮される最大の活動量のうち, 運動にか かわった結果の筋活動量が異なっていたということ を示す。これまで，両筋は単一筋として扱われてお り，2つの筋の機能的差異は明らかとされてこなか ったが，方法的限界の克服と外転運動中に㧈ける両 

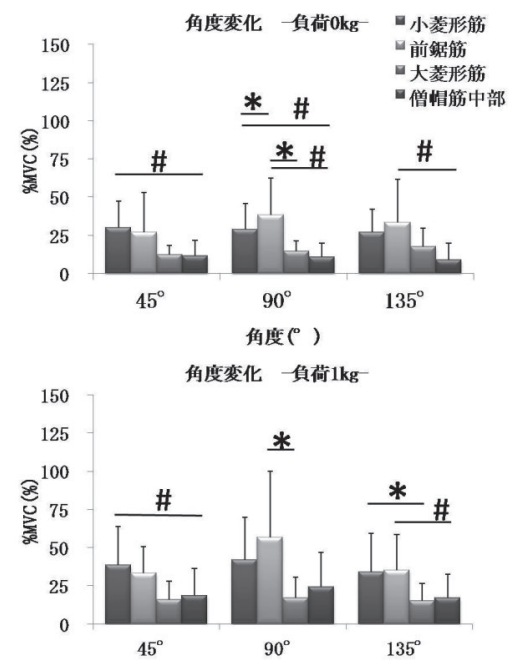

角度 $\left({ }^{\circ}\right)$

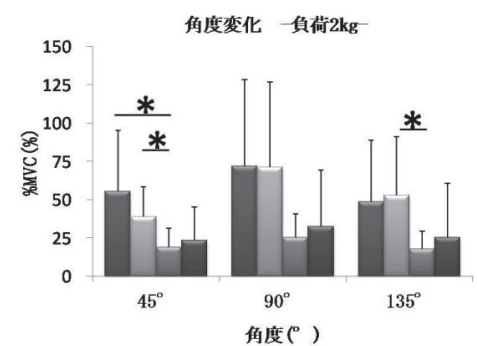

図 5 ある一定角度における各筋筋活動量変化（出典：執筆 者）

筋間の筋活動量に相違が見られることから，両筋間 では肩関節外転運動による肩甲骨の移動に対する機 能的役割が異なる可能性が考えられた。

また，小菱形筋と前鋸筋の筋活動量は負荷上昇に 伴い外転初期から増加し，外転後期に扔いても高い 筋活動量を示していた。これまでの肩甲骨周囲筋群 を対象とした筋電図学的及び運動学的研究では，多 くが前鋸筋と僧帽筋における偶力の存在及び関係に ついて述べている，前鋸筋については，筋出力及び 機能低下が，肩甲胸郭関節における異常な運動を招 き，肩甲上腕関節の不安定性 ${ }^{24,25)}$ に結びつくとの報 告もある。このことから前鋸筋の肩関節運動への関 与の高さが分かる。また立位での肩関節外転運動で は，肩甲骨上方回旋及び肩甲骨胸郭保持の役割を担 う前鋸筋の筋活動は高くなるとの報告もある ${ }^{12,26)}$. 本研究では, 前鋸筋の筋活動量は外転後期で次第に
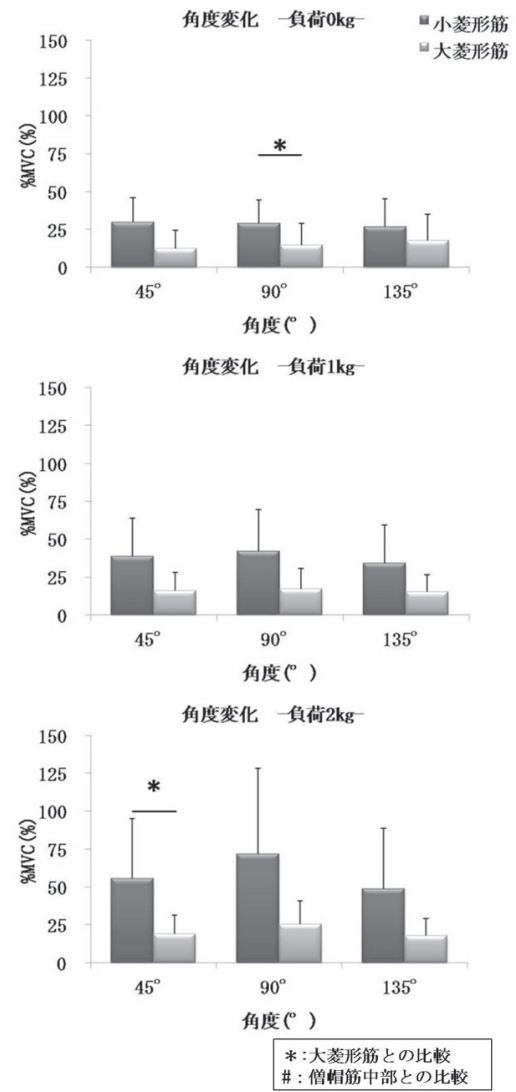

図 6 ある一定角度における大・小菱形筋間の筋活動量変化 （出典：執筆者）

増加する傾向にあった．特に外転 $75\left[^{\circ}\right]$ の筋活動量 を比較すると，負荷 $0[\mathrm{~kg}]$ の時は 40[\% MVC] で あるのに対し，負荷 2[kg] では 70[\% MVC]を超え ていた。また，小菱形筋は $45\left[^{\circ}\right]$ までの外転初期の 筋活動量が負荷増加に伴い増加し, 以降一定の高い 筋活動量を示した，両筋は前述したように筋張力が 拮抗して作用する関係であると考えられていること から，肩関節外転運動では，負荷依存的に活動量が 変化し，拮抗した方向へ張力を発揮することで肩甲 骨を胸郭に引きつける作用を果たしていることが考 えられる。

本研究で対象とした被験者間では, 特に大・小菱 形筋に関して個人間での筋活動量に若干のばらつき が見られた。これには，前述したとおり MMT肢 位による最大の筋力発揮能力や肩甲上腕関節や肩甲 胸郭関節の可動域の違いが関与しているものと予測 
する。

本研究の新規性は従来十分に明らかにされてこな かった，菱形筋を中心とした肩甲骨周囲筋の機能を 解明するための基礎的知見として，外転運動におけ る大・小菱形筋の筋活動量とその差異を示した点で ある。今後は菱形筋を中心とした肩甲骨周囲筋群と 肩関節周囲筋の筋活動の関係, あるいは肩甲骨の運 動との関連性について解明するための研究が求めら れる。

\section{5. 結論}

本研究により，大・小菱形筋間において，肩関節 外転運動時の相対的な筋活動量の動態が異なってい ることが示された。また，肩関節外転運動時小菱形 筋と前鋸筋は負荷依存的に活動量を変化させている ことが明らかとなった，小菱形筋と前鋸筋は互いの 張力を拮抗させることにより肩甲骨を胸郭に保持し ているものと推察する.

このように, 肩甲胸郭関節は肩甲骨周囲筋群の協 調運動により保持されているものと考える。

\section{参考文献}

1) Cools, A.M., Witvrouw, E.E., Mahieu, N.N. and Danneels, L.A.: Isokinetic Scapular Muscle Performance in Overhead Athletes With and Without Impingement Symptoms, J Athl Train, 40 (2), 104-110, (2005).

2) Kibler, W.B.: Biomechanical analysis of the shoulder during tennis activities, Clin Sports Med, 14(1), 79-85, (1995).

3) Kibler, W.B., Chandler, T.J., Shapiro, R. and Conuel, M.: Muscle activation in coupled scapulohumeral motions in the high performance tennis serve, Br J Sports $\mathrm{Med}, 41$ (11), 745-749, (2007).

4) Lin, J.J., Hanten, W.P., Olson, S.L., Roddey, T.S., SotoQuijano, D.A., Lim, H.K. and Sherwood, A.M.: Functional activities characteristics of shoulder complex movements: Exploration with a 3-D electromagnetic measurement system, J Rehabil Res Dev, 42(2), 199-210, (2005).

5) Johansen, R.L., Callis, M., Potts, J. and Shall, L.M.: A modified internal rotation stretching technique for overhand and throwing athletes, J Orthop Sports Phys Ther, 21 (4), 216-219, (1995).

6) Burkhart, S.S., Morgan, C.D. and Kibler, W.B.: The disabled throwing shoulder: spectrum of pathology Part III: The SICK scapula, scapular dyskinesis, the kinetic chain, and rehabilitation, Arthroscopy, 19(6), 641-661,
(2003).

7) Ludewig, P.M., Hoff, M.S., Osowski, E.E., Meschke, S.A. and Rundquist, P.J.: Relative balance of serratus anterior and upper trapezius muscle activity during pushup exercises, Am J Sports Med, 32(2), 484-493, (2004).

8) Kibler, W.B.: The role of the scapula in athletic shoulder function, Am J Sports Med, 26 (2), 325-337, (1998).

9) Inman, V.T., Saunders, J.B. and Abbott, L.C.: Observations of the function of the shoulder joint. , Clin Orthop Relat Res, 26(1), 1-30, (1944).

10）金子文成：回旋筋腱板を構成する 4 筋の投球動作中筋電 図に関する連続時系列的分析, 関節外科, 28(11), (2009.11).

11）金子文成, 車谷洋, 増田正, 村上恒二, 山根雅仁：投球 動作に打ける肩関節周囲筋筋電図の連続時系列変化に関 する分析, 理学療法学, 32(3), 115-122, (2005).

12) Bagg, S.D. and Forrest, W.J.: A biomechanical analysis of scapular rotation during arm abduction in the scapular plane, Am J Phys Med Rehabil, 67(6), 238-245, (1988).

13) Ebaugh, D.D., McClure, P.W. and Karduna, A.R.: Threedimensional scapulothoracic motion during active and passive arm elevation, Clin Biomech (Bristol, Avon), 20 (7), 700-709, (2005).

14) Fayad, F., Hoffmann, G., Hanneton, S., Yazbeck, C., Lefevre-Colau, M.M., Poiraudeau, S., Revel, M. and RobyBrami, A.: 3-D scapular kinematics during arm elevation: effect of motion velocity, Clin Biomech (Bristol, Avon), 21 (9), 932-941, (2006).

15) Bagg, S.D. and Forrest, W.J.: Electromyographic study of the scapular rotators during arm abduction in the scapular plane, Am J Phys Med, 65 (3), 111-124,(1986).

16) Cools, A.M., Witvrouw, E.E., Declercq, G.A., Vanderstraeten, G.G. and Cambier, D.C.: Evaluation of isokinetic force production and associated muscle activity in the scapular rotators during a protraction-retraction movement in overhead athletes with impingement symptoms, Br J Sports Med, 38 (1), 64-68, (2004).

17) Minning, S., Eliot, C.A., Uhl, T.L. and Malone, T.R.: EMG analysis of shoulder muscle fatigue during resisted isometric shoulder elevation, J Electromyogr Kinesiol, 17(2), 153-159, (2007).

18) Yoshizaki, K., Hamada, J., Tamai, K., Sahara, R., Fujiwara, T. and Fujimoto, T.: Analysis of the scapulohumeral rhythm and electromyography of the shoulder muscles during elevation and lowering: comparison of dominant and nondominant shoulders, J Shoulder Elbow Surg, 18(5), 756-763, (2009).

19) Forte, F.C., de Castro, M.P., de Toledo, J.M., Ribeiro, D.C. and Loss, J.F.: Scapular kinematics and scapulohumeral rhythm during resisted shoulder abduction-implications for clinical practice, Phys Ther Sport, 10(3), 105-111, (2009).

20) Sahara, W., Sugamoto, K., Murai, M., Tanaka, H. and Yoshikawa, H.: The three-dimensional motions of glenohumeral joint under semi-loaded condition during arm abduction using vertically open MRI, Clin Biomech (Bristol, Avon), 22(3), 304-312, (2007).

21) Sugamoto, K., Harada, T., Machida, A., Inui, H., Miya- 
moto, T., Takeuchi, E., Yoshikawa, H. and Ochi, T.: Scapulohumeral rhythm: relationship between motion velocity and rhythm, Clin Orthop Relat Res, 401), 119124, (2002).

22) Neumann, D.A.: Kinesiology of the musculoskeletal system: foundations for physical rehabilitation, Mosby, (2002).

23) McQuade, K.J., Dawson, J. and Smidt, G.L.: Scapulothoracic muscle fatigue associated with alterations in scapulohumeral rhythm kinematics during maximum resistive shoulder elevation, J Orthop Sports Phys Ther, 28(2), 74-80, (1998)

24) Decker, M.J., Hintermeister, R.A., Faber, K.J. and
Hawkins, R.J.: Serratus anterior muscle activity during selected rehabilitation exercises, Am J Sports Med, 27 (6), 784-791, (1999).

25) Matias, R. and Pascoal, A.G.: The unstable shoulder in arm elevation: a three-dimensional and electromyographic study in subjects with glenohumeral instability, Clin Biomech (Bristol, Avon), 21 Suppl 1(S52-58, (2006).

26) Faria, C.D., Teixeira-Salmela, L.F., Goulart, F.R. and Gomes, P.F.: Comparisons of electromyographic activity of scapular muscles between elevation and lowering of the arms, Physiother Theory Pract, 24(5), 360-371, (2008).

\title{
A Muscle Activity Characteristics of the Scapular Muscles during the Shoulder Abduction -Focus on the Rhomboid Muscle-
}

\author{
Motozumi $\mathrm{KITSUNAI}^{1 \dagger}$, Fuminari KANEKO ${ }^{2,3}$, Toshiyuki AOYAMA ${ }^{4}$, Hajime TODA $^{4}$, \\ Toru FUKUBAYASHI ${ }^{5}$
}

${ }^{1}$ Graduate School of Sport Sciences, Waseda University, ${ }^{2}$ School of Health Sciences, Sapporo Medical University, ${ }^{3}$ Institute for Human Science and Biomedical Engineering, Advanced Industrial Science and Technology, ${ }^{4}$ Graduate School of Health Sciences, Sapporo Medical University, ${ }^{5}$ Faculty of Sport Sciences, Waseda University

\begin{abstract}
The present study investigated the muscle activity characteristics of scapular muscles, mainly the rhomboid muscle, during shoulder movement. The study population comprised 6 male college students with no history of shoulder injury. We recorded the EMG of some scapular muscles during shoulder abduction: the rhomboid major and minor muscles were tested using a wire electrode; the serratus anterior and the middle trapezius, by a surface electorode. It was found that with the increase in the shoulder angle and load, the muscle activity of each scapular muscle increased significantly. In particular, the muscle activity differed between rhomboid minor and major muscles, and it was believed that the muscle activity of the rhomboid minor and serratus anterior increased with load. Therefore, it was thought that the rhomboid minor and serratus anterior muscles show load dependence, and the possibility that the coordinated movement between the muscles plays a role in the maintenance of the scaplothoratic joint during shoulder abduction was suggested.
\end{abstract}

Key Words: Rhomboid muscle, Trapezius muscle, Scapulothoratic joint, Wire-EMG, Overhead sport 